Professor, Doctor of Economics Anatoliy Zemtsov,

Department of Finance and Accounting,

National Research Tomsk State University,

Russia

Associate professor, candidate of economic sciences, Olga Nikulina,

Department of Finance and Accounting,

National Research Tomsk State University,

Russia

\title{
THE ECONOMIC CONCEPT OF THE TAX CODE: INITIAL POSITION
}

A lthough recent years have brought about changes in tax relations in Russia, the imperfection of tax administration remains a serious problem, increasing the total tax burden on taxpayers. The global financial crisis has exacerbated the situation. The end of almost eight years of the budget surplus in Russia has evoked the need to find new sources of revenue and ensure completeness of tax payment ${ }^{1}$.

Methodologically, the sequence of events plays a critical role in the development of tactics and strategy of any financial reform and restructuring. Incorporating only financial and legal methods, it is impossible to achieve the planned results. And it is difficult to object to V.G. Panskov that it is contrary to the Ministry of Finance of the Russian Federation and that the tax reform is far from complete in the first place because there is no economic concept, without which many rewritings of the Tax Code do not have much influence upon the final result ${ }^{2}$.

In this regard, I would like to highlight a number of points that are very relevant when considering the improvement of the concept of the Tax Code.

1) A wide definition of meaningful tax, which includes all types of income accruing to the state on a regular basis with the help of law enforcement belonging to it $^{3}$, requires the inclusion of taxes paid by a taxpayer in the Special Part of the Tax Code .

In connection with this very interesting approach, Lawyers of "Pepeliaev Group" seem to claim the same, i.e. that a situation with multiple payments is not embedded in the overall tax system, and a degree of certainty of the value of the total burden (the severity of) imposing mandatory payments aimed at the implementation of public functions should be reduced. The actual severity of taxation is different than you might think based on the content of the Tax Code ${ }^{4}$.

2) Structuring the Tax Code in the aspect of the subjective rights of taxpayers as a ratio of the parties: the taxpayer and the receiver of taxes (state), the introduction of the principle of equivalence. Thus, taxation should be seen as a process which is binding on the participants: the taxpayer and the receiver of taxes (state), where the taxpayer seeks to reduce taxes and the state - prevent the reduction of income tax to the treasury.

Creating tax systems and, at the same time, providing the implementation of the state's functions and an increase of business activity of citizens, enterprises, municipalities and regions, have always been and will be the subject of a debate and a "battle" between different branches of the government and business. Thus, the problem of creating a tax system that provides balance, harmony, social justice and economic efficiency remains unsolved ${ }^{5}$.

3) The inclusion of a chapter or section of the potential tax burden (as a calculation of the average rate) in the business. This task is not implemented to date and potential business representatives do not have a real picture which would give a complete picture of the level of taxation of their business.

Fiscal burden in Russia - one of the highest in the world, is much higher than in most developed and developing 
countries (about $50 \%$ of GDP according to the IMF methodology $)^{6}$.

In the ranking of 2015, the tax burden in Russia amounted to $48.9 \%$ of the profits (including income tax $-8.4 \%$, insurance premiums $-35.4 \%$, other taxes $-5.1 \%)^{7}$. In this regard, a representative of any type of business often does not address the issue of options which is to reduce tax costs and minimize their tax burden on legitimate business level and this, in turn, leads to thinking about getting a tax benefit. Data findings provided by A.A. Yakovlev denote that the shady schemes of interaction of subjects of the Russian economy are its bad practice ${ }^{8}$.

Until now, the tax legislation has not provided a clear division of concepts to optimize tax payments and tax evasion, entailing a tax and criminal liability for illegal circumvention of taxes. The main reason for the increase of tax risks is related to the fact that previously developed tax optimization schemes have been considered quite often as illegal9 .

4) Providing direct fulfillment of tax obligations of taxpayers excluding the tax agency ${ }^{10}$.

The tax legislation mixes the status of tax agents and taxpayers by giving them equal rights. Shortcomings of the current legislation on taxes and fees, generate much controversy in the theory of tax law and, consequently, affect the law enforcement practice ${ }^{11}$.

The subject science has hardly studied the effect of the duties of a tax agent on their own financial and economic situation, have not analyzed the limits within which the subject can be bound to perform the functions to calculate, withhold and remit taxes, carrying risks of accrual of penalties and prosecutions as a taxpayer and by virtue of a tax agent status ${ }^{12}$.

5) The inclusion of the concept of the Tax Code in indirect taxation section. This is a confirmation and delimitation of the concepts of "tax vehicle" and the taxpayer.

Both legislation and legal doctrine perceive it as a direct tax. Thus, the rights and legitimate interests of third parties, which are understood as true taxpayers in indirect taxation - consumer goods, works and services which are subject to turnover, have been totally abandoned by the legislator ${ }^{13}$.

Thus, there is a need to reform and restructure the Tax Code of the Russian Federation in view of the foregoing.

\section{BIBLIOGRAPHY}

1. Dzhaarbekov S., company - ephemera, http://taxslov.ru.
2. Havanova I.A., Tax agents: the status of the transformation into a modern model of taxation, "AF" 2014, № 4.

3. Karaseva M.V. (Sentsova), Tax and civil law, new aspects of the relationship, in: M.V. Karaseva (Sentsova) (ed.), Public Finance and Tax Law: Yearbook, vol. 2, Budget and tax reforms in the countries of Central and Eastern Europe, Voronezh 2011.

4. Korshunova M.V., On the application of the taxpayer public criteria for assessing tax risks, “Tax” 2009, № 1.

5. Kuznechenkov E.V., Features of procedural status of tax agents, "Financial Law" 2006, № 7.

6. Markin Y.M., Traps competitiveness, “Banking” 2010, № 12.

7. Sadkov V.G., Aronov D.V., Melnikov S.A., Fedyakovo N.I., Myths about the excessive tax burden on business and the key areas of modernization of the Russian tax system, eliminating its real flaws, "Finance and Credit" 2009, № 13 (349).

8. Zapolskiy S.V., The theory of financial law: scientific essays, M ., RAP, 2010.

9. Zaripov V., Popov P., Romashchenko L., Concept of improving the legal regulation of non-codified taxes and fees, in: M.V. Karaseva (Sentsova) (ed.), Public Finance and Tax Law: Yearbook, vol. 5, Target public funds and non-tax payments in the countries of Central and Eastern Europe, Voronezh 2015.

10. Yakobson L.I., Economy of the public sector, M ., 2016.

11. Yakovlev A.A., upgrading Agents [Text], in: A.A. Yakovlev, Gos. University - Higher School of Economics, M., Publishing. HSE house, 2006.

12. Zapolskiy S.V., The theory of financial law: scientific essays, M ., RAP, 2010.

13. Zemtsov A.A., Nikulina O.M., Institute of tax agents in Russia: economic view, "Russian justice" 2015, № 12.

M.V. Karaseva (Sentsova), Tax and civil law, new aspects of the relationship, in: M.V. Karaseva (Sentsova) (ed.), Public Finance and Tax Law: Yearbook, vol. 2, Budget and tax reforms in the countries of Central and Eastern Europe, Voronezh 2011, p. 349.

S.V. Zapolskiy, The theory of financial law: scientific essays, M., RAP, 2010, p. 35-36.

L.I. Yakobson, Economy of the public sector, M., 2016, p. 119.

V. Zaripov, P. Popov, L. Romashchenko, Concept of improving the legal regulation of non-codified taxes and fees, in: M.V. Karaseva (Sentsova) (ed.), Public Finance and Tax Law: Yearbook, vol. 5, Target public funds and non-tax payments in the countries of Central and Eastern Europe, Voronezh 2015, p. 83.

V.G. Sadkov, D.V. Aronov, S.A. Melnikov, N.I. Fedyakovo, Myths about the excessive tax burden on business and the key areas of modernization of the Russian tax system, eliminating its real flaws, "Finance and Credit" 2009, № 13 (349), p. 19.

Y.M. Markin, Traps competitiveness, "Banking” 2010, № 12, p. 35.

S. Dzhaarbekov, company - ephemera, http://taxslov.ru/n180.htm

A.A. Yakovlev, upgrading Agents [Text], in: A.A. Yakovlev, Gos. University - Higher School of Economics, M., Publishing. HSE house, 2006, p. 15

M.V. Korshunova, On the application of the taxpayer public criteria for assessing tax risks, “Tax” 2009, № 1, p. 25.

${ }_{10}$ A.A. Zemtsov, O.M. Nikulina, Institute of tax agents in Russia: economic view, "Russian justice" 2015, № 12, p. 37 - 41.

"E.V. Kuznechenkov, Features of procedural status of tax agents, "Financial Law" 2006, № 7, p. 10.

${ }^{12}$ I.A. Havanova, Tax agents: the status of the transformation into a modern model of taxation, “AF" 2014, № 4, p. 43.

${ }^{13}$ S.V. Zapolskiy, The theory of financial law: scientific essays, M., RAP, 2010, p. 309. 